\title{
A $30 \mathrm{Myr}$ record of Late Triassic atmospheric $p \mathrm{CO}_{2}$ variation reflects a fundamental control of the carbon cycle by changes in continental weathering
}

\author{
Morgan F. Schaller ${ }^{1, \uparrow}$, James D. Wright ${ }^{1}$, and Dennis V. Kent ${ }^{1,2}$ \\ ${ }^{1}$ Department of Earth and Planetary Sciences, Rutgers University, Piscataway, New Jersey 08854, USA \\ ${ }^{2}$ Lamont Doherty Earth Observatory, Columbia University, Palisades, New York 10964, USA
}

\section{ABSTRACT}

We generate a detailed $\sim 30 \mathrm{Myr}$ record of $p \mathrm{CO}_{2}$ spanning most of the Late Triassic (Carnian-Norian-Rhaetian) to earliest Jurassic (Hettangian), based on stable carbon isotope ratios of soil carbonate and preserved organic matter from paleosols in the eastern North American Newark rift basin. Atmospheric $\mathrm{pCO}_{2}$ was near $4500 \mathrm{ppm}$ in the late Carnian, decreasing to below $\sim 2000 \mathrm{ppm}$ by the late Rhaetian just before the earliest Jurassic eruption of the Central Atlantic Magmatic Province, which triggered measurable pulses of $\mathrm{CO}_{2}$ outgassing. These data are consistent with published modeling results using the GEOCLIM model, which predict a decrease in $\mathrm{pCO}_{2}$ over the Late Triassic as a result of the progressive increase in continental area subject to the intense weathering regime of the tropical humid belt due to Pangea's northward motion. The finer-scale $p \mathrm{CO}_{2}$ changes we observe may be dependent on the lithology introduced to the tropics, such as the dip to $\sim 2000 \mathrm{ppm}$ around $212 \mathrm{Ma}$ and its rebound to $\sim 4000 \mathrm{ppm}$ at $209 \mathrm{Ma}$, which can be accomplished by introducing a more weatherable subaerial basaltic terrain. These observations indicate that the consumption of $\mathrm{CO}_{2}$ by continental silicate weathering can force long-term changes in $p \mathrm{CO}_{2}$ comparable to those driven by presumed changes in mantle degassing.

\section{INTRODUCTION}

On geologic time scales, equable climates are controlled primarily by a balance between the $\mathrm{CO}_{2}$ outgassed at mid-ocean ridges and other volcanoes and the consumption of that $\mathrm{CO}_{2}$ by

${ }^{\dagger}$ Current address: Earth and Environmental Science, Rensselaer Polytechnic Institute, Troy, New York 12180, USA; e-mail: schall@ rpi.edu. silicate weathering reactions on the continents. Because $\mathrm{CO}_{2}$ exerts a fundamental control over temperature, and temperature influences precipitation patterns (Manabe and Wetherald, 1980) and determines the rate constants in continental hydrolysis reactions (for review, see Kump et al., 2000), an increase in atmospheric $p \mathrm{CO}_{2}$ ultimately leads to an increase in chemical weathering. Increased weathering more rapidly consumes $\mathrm{CO}_{2}$, leading to an eventual negative feedback on atmospheric $p \mathrm{CO}_{2}$, thus constituting a "thermostat" that keeps Earth's temperature within a stable range (Walker et al., 1981). One way to tip the balance in this relationship is to change the rate of $\mathrm{CO}_{2}$ degassed from Earth's mantle. This perspective has led to a generation of carbon-cycle mass-balance models (e.g., BLAG and GEOCARB [Berner, 1990, 2006; Berner and Kothavala, 2001; Berner et al., 1983], COPSE [Bergman et al., 2004]) that force long-term (geologic scale) changes in $\mathrm{pCO}_{2}$ by the cumulative effects of transient changes in the rate of degassing at mid-ocean ridges (Fig. 1), treating the weathering-induced consumption of atmospheric $\mathrm{CO}_{2}$ as a simple feedback response (Berner, 1991).

Such source-side processes have dominated attempts to explain the evolution of atmospheric $p \mathrm{CO}_{2}$ on time scales like the Phanerozoic, with the only substantial suggested sink-side perturbations thought to be related to uplift during a massive orogenic event such as the Himalayas (e.g., Raymo and Ruddiman, 1992). However, this simplified view of the system does not account for tectonic-scale changes in the distribution of continental area with respect to the zones on Earth's surface where weathering is most active (Donnadieu et al., 2006a, 2006b; Goddéris et al., 2008), or the relocation or eruption of highly weatherable material into the equatorial humid belt (Dessert et al., 2001; Kent and Muttoni, 2008, 2013; Schaller et al., 2012). These alternate explanations for $10^{6}$ - to $10^{7}$-yr-scale $p \mathrm{CO}_{2}$ variability constitute sink- side processes that are functions of the spatial, temporal, and lithologic heterogeneity of continental surface participation in weathering reactions. These effects are independent of changes in mid-ocean ridge degassing, but they can impart variability of the same magnitude.

The Late Triassic offers a unique opportunity to empirically test whether variations in the sink side (continental weathering) of the global carbon cycle can drive long-term changes in atmospheric $p \mathrm{CO}_{2}$. This is because the rates of ocean crust production, based on inversion of sea-level records used in simple mass-balance models, apparently changed little through the Late Triassic (Fig. 1; Gaffin, 1987), thereby severely limiting any $p \mathrm{CO}_{2}$ forcing incorporated in the BLAG/GEOCARB models over this time interval, which indeed produce a flat $p \mathrm{CO}_{2}$ profile (see previously cited references). On the other hand, Goddéris et al. (2008) found that the northward migration of Pangea during the Triassic should have produced a two-thirds modeled reduction of atmospheric $p \mathrm{CO}_{2}$ by the latest Triassic, due to a steady increase in the amount of weatherable land area present in the tropical humid belt. Therefore, given the lack of any appreciable source-side forcing during the Late Triassic we predict that any significant observed change in atmospheric $p \mathrm{CO}_{2}$ through the interval must be forced by another mechanism.

In this paper, we empirically test the hypothesis that continental weathering can be the primary control over the long-term evolution of $p \mathrm{CO}_{2}$ through changes in the latitudinal distribution of continental area, as modeled with GEOCLIM by Goddéris et al. (2008), by generating an atmospheric $p \mathrm{CO}_{2}$ record from the $\sim 30$ Myr continuous section of Late Triassic continental strata of the Newark rift basin in eastern North America (Fig. 2). We use the stable carbon isotope ratios of pedogenic carbonate and soil organic matter as a proxy for atmospheric $p \mathrm{CO}_{2}$ (Cerling, 1999), which has been successfully used to estimate the transient $p \mathrm{CO}_{2}$ perturbations

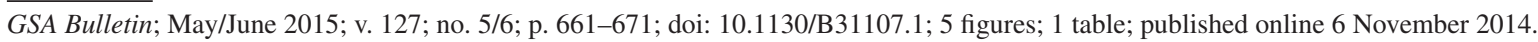




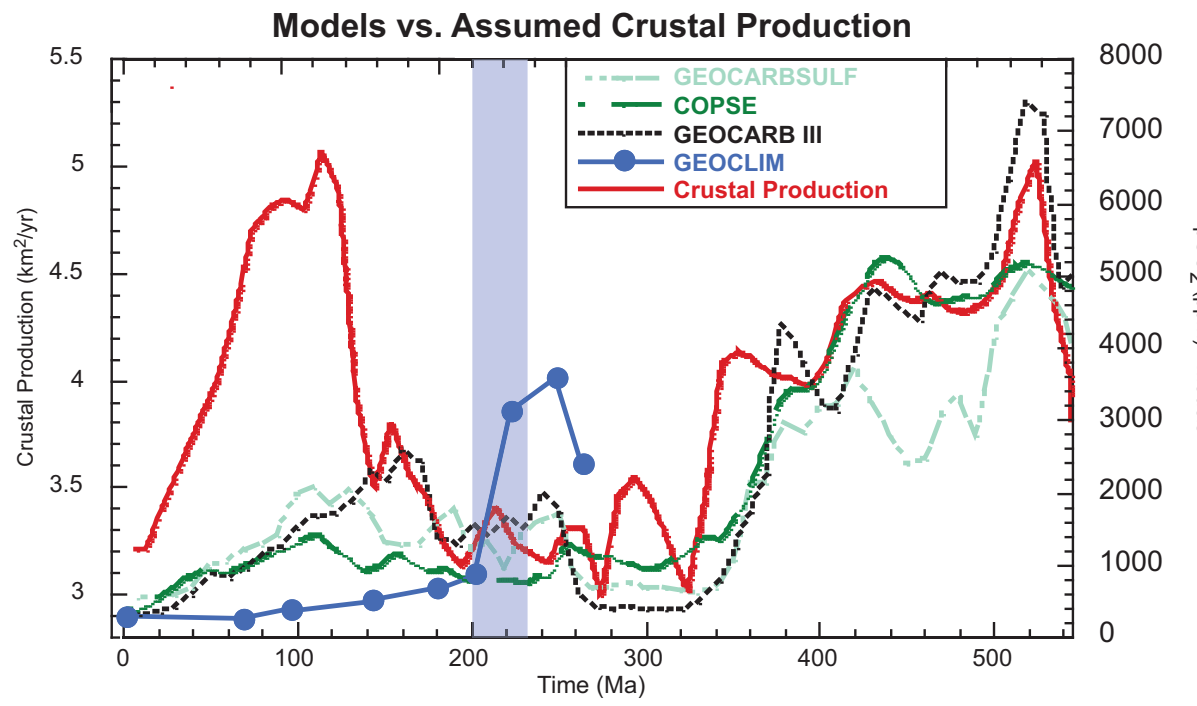

Figure 1. The $\mathrm{pCO}_{2}$ output of several geochemical models over the Phanerozoic, GEOCARBIII (Berner and Kothavala, 2001); GEOCARBsulf (Berner, 2006); COPSE (Bergman et al., 2004); GEOCLIM (Donnadieu et al., 2006a; Goddéris et al., 2008), compared to the record of assumed crustal production used in the GEOCARB models (from Gaffin, 1987), which is based on inversion of sea-level histories determined by sequence stratigraphy. All models except GEOCLIM are based on the BLAG hypothesis. Shaded band is Late Triassic (ca. 201-235 Ma).

associated with the Central Atlantic magmatic province (Schaller et al., 2011, 2012), situated in the upper portion of the eastern North America section. The $p \mathrm{CO}_{2}$ estimates presented here from the underlying $\sim 4500 \mathrm{~m}$ of section show a secular decrease between the Carnian and Rhaetian, consistent with the results of GEOCLIM, which modeled this decrease as a function of the amount and rate at which continental area is moved into the equatorial humid belt, where atmospheric $\mathrm{CO}_{2}$ is most efficiently consumed.

\section{ESTIMATES OF $p \mathrm{CO}_{2}$ FROM PALEOSOLS}

The paleosol samples used in this study were taken from a series of long cores through the sedimentary strata of the Newark rift basin in eastern North America acquired by the Newark Basin Coring Project (NBCP; Kent et al., 1995; Olsen et al., 1996). Sediments filling this half graben are primarily shallow to deep lacustrine facies, with fluvial and pedogenic facies sporadically throughout (Olsen, 1997; Smoot, 1991), deposited in tropical latitudes (Kent et al., 1995; Kent and Tauxe, 2005), though the lowermost unit (the Stockton Formation) is mostly fluvial. The seven individual NBCP cores comprise a complete and continuous $\sim 5000 \mathrm{~m}$ composite stratigraphic section, spanning the mid-Carnian of the Late Triassic to the Hettangian of the Early Jurassic (see Fig. 2). The boreholes (stratigraphically upward: Princeton, Nursery, Titusville, Rutgers, Somerset, Weston Canal, and Martinsville) were spudded in the NW-dipping strata for maximum overlap up section, and even those sites that are as much as $\sim 50 \mathrm{~km}$ geographically apart (e.g., the Rutgers and Titusville cores) show nearly identical stratigraphy within the zones of overlap.

The lacustrine facies are ordered in a rhythmic succession reflecting periodic fluctuations in lake depth that have been related directly to Milankovitch orbital forcing of tropical precipitation (Olsen, 1986; Olsen and Kent, 1996; Van Houten, 1962). This record of orbitally forced sedimentation provides the precise astronomical chronometer used to construct the geomagnetic polarity time scale for more than $30 \mathrm{Myr}$ of the Late Triassic and Early Jurassic (Kent and Olsen, 1999; Kent et al., 1995; Olsen and Kent, 1996, 1999), making these $p \mathrm{CO}_{2}$ estimates both temporally precise and globally relevant.

Organic and inorganic carbon isotope measurements from these paleosols were used to estimate $C_{a}$, the concentration of atmospheric $\mathrm{CO}_{2}$, according to the soil diffusion model of Cerling (1999):

$$
C_{a}=S(z) \frac{\delta_{\mathrm{s}}-1.0044 \delta_{\varphi}-4.4}{\delta_{\mathrm{a}}-\delta_{\mathrm{s}}},
$$

where $S(z)$ is the concentration of $\mathrm{CO}_{2}$ at soil depths greater than $50 \mathrm{~cm}$ contributed by the respiration of soil organic matter, $\delta_{\mathrm{s}}$ is the $\delta^{13} \mathrm{C}$ of soil $\mathrm{CO}_{2}, \delta_{\varphi}$ is the $\delta^{13} \mathrm{C}$ of soil-respired $\mathrm{CO}_{2}$, and $\delta_{\mathrm{a}}$ is the $\delta^{13} \mathrm{C}$ of atmospheric $\mathrm{CO}_{2}$. All $\delta$ values are relative to Vienna Peedee belemnite (VPDB).

The carbon isotope ratio of soil carbonate $\left(\delta_{c c}\right)$ is used as a proxy for $\delta_{s}$, which involves a temperature-dependent equilibrium fractionation between calcite and $\mathrm{CO}_{2}$, described by (Cerling, 1999):

$$
\begin{aligned}
10^{3} \ln \alpha= & 11.709-0.116(\mathrm{~T})+ \\
& 2.16 \times 10^{-4}(\mathrm{~T})^{2},
\end{aligned}
$$

where $\alpha$ is the fractionation factor, and temperature $\left(\mathrm{T}\right.$, in $\left.{ }^{\circ} \mathrm{C}\right)$ is fixed at $25^{\circ} \mathrm{C}\left( \pm 5^{\circ} \mathrm{C}\right)$, which is assumed to be appropriate for the tropical Newark basin. For the purposes of this work, Equation 2 gives results indistinguishable from the Romanek et al. (1992) calibration at $25^{\circ} \mathrm{C}$. Because there is no kinetic or equilibrium carbon isotope fractionation due to respiration, $\delta_{\varphi}$ is related directly to the carbon isotopic ratio of soil organic matter $\left(\delta^{13} \mathrm{C}_{\text {org }}\right.$ ) (see following discussion). The carbon isotopic ratio of the atmosphere is calculated from the measured $\delta^{13} \mathrm{C}_{\text {org }}$ by the following relationship (Arens et al., 2000):

$$
\delta_{\mathrm{a}}=\left(\delta^{13} \mathrm{C}_{\mathrm{org}}+18.67\right) / 1.10
$$

which assumes consistent fractionation by photosynthesis and builds carbon-cycle perturbations directly into the model. We note that there is a change in the degree of photosynthetic fractionation by terrestrial plants in response to elevated atmospheric $\mathrm{CO}_{2}$ (Schubert and Jahren, 2012). Though this is an important effect, it is difficult to include in the model at this time because of its fundamental dependence on $p \mathrm{CO}_{2}$. Marine carbonate records provide good evidence that the $\delta^{13} \mathrm{C}$ value of the atmosphere has not changed substantially over the long-term (e.g., see Schidlowski, 2001), with the exception of major transient carbon-cycle perturbations. The use of a constant photosynthetic fractionation is an attempt to account for potential perturbations, while the alternative is to assume a $\delta^{13} \mathrm{C}$ value of atmospheric $\mathrm{CO}_{2}$ of $-5 \%$ o to $-6 \%$ o. We also note that the $\delta^{13} \mathrm{C}$ of the atmosphere has only a very small effect on the resultant calculated $\mathrm{pCO}_{2}$ (roughly $200 \mathrm{ppm}$ for each $1 \%$ change).

The only freely adjustable parameter of the model is the concentration of $\mathrm{CO}_{2}$ in the soil derived from the respiration of organic matter $(S[z])$, which is a function of soil productivity. The paleosols sampled in this study were relatively productive argillic and vertic Calcisols 


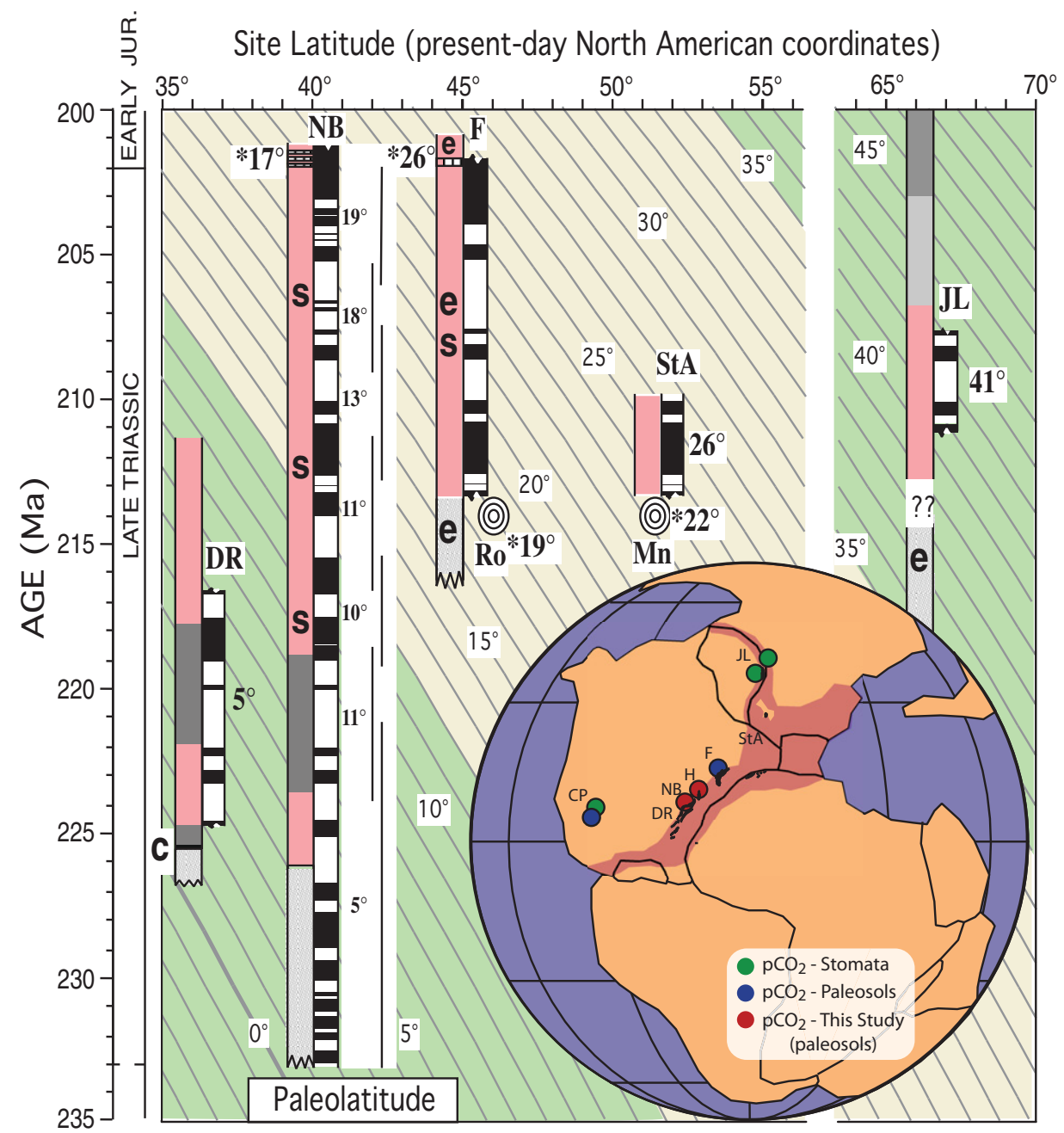

Figure 2. Paleolatitude nomogram for the Late Triassic and earliest Jurassic (modified from Kent and Tauxe, 2005). The paleolatitude contours are based on corrected mean inclinations from the Newark Basin Coring Project (NBCP) cores. Stratigraphic interval of the Newark Basin (NB) covered by each core is represented by the black bars, with corrected paleolatitudes listed adjacent. Green and tan shading represents broad-scale climate zones delineated by present-day evaporation minus precipitation, $\mathbf{E}-\mathbf{P}$. Site latitudes for the Jameson Land (JL) section in Greenland, the St. Audrie's Bay (StA) section, and the 214 Ma Rochechouart impact structure (Ro) in Europe were transferred to North American coordinates (see Kent and Tauxe, 2005, and references therein). The geomagnetic polarity time scale from the Newark Basin cores (Kent and Olsen, 1999) was used as the basis of magnetostratigraphic correlation (filled/open bars denote normal/reverse polarity) and age control. Mean paleolatitudes from corrected inclinations are indicated for Jameson Land, St. Audrie's Bay, and Dan River (DR) basin. Paleolatitudes with asterisks are for igneous rocks from earliest Jurassic (ca. 200 Ma) Central Atlantic magmatic province lavas in Newark Basin and Fundy Basin (F), and from the 214 Ma Manicougan impact structure (Mn) in Quebec, and the Rochechouart impact structure (Ro). Letters denote climate lithofacies: c-coal, s-saline minerals and e-eolian deposits; light to dark shading in lithology columns ranges from fine-grained red beds to black shales with stippling indicating sandstones. Inset map is a schematic reconstruction of Pangean paleogeography showing the locations of sampling sites reported in this study (red circles), other locations with paleosol $p \mathrm{CO}_{2}$ estimates (blue circles), and $p \mathrm{CO}_{2}$ estimates from plant stomata (green circles) (H-Hartford Basin, $\mathrm{CP}-$ Colorado Plateau; other abbreviations as above).
(Mack et al., 1993), the majority of which are Vertisols with abundant, often prismatic peds bounded by intersecting slickensides generally above, or within, the upper portion of the Bk (carbonate accumulating) horizon. The Bk horizon is only occasionally indurated and generally ranges from stage II to III of development, and small, isolated nodules are common above the main Bk horizon. The mean depth to the Bk horizon $\left(D_{\mathrm{s}}\right)$ of these soils is $40 \pm 15 \mathrm{~cm}$ soil depth (where measurable, undecompacted), which we used to estimate $S(z)$ by the following empirical relationship (Retallack, 2009b):

$$
S(z)=66.7 D_{\mathrm{s}}+588 .
$$

This results in a mean $S(z)$ of $\sim 3256$, with an empirical standard error (SE) of $\pm 893 \mathrm{ppm}$ (Retallack, 2009b). Given the difficulty inherent in accurately estimating depth to the Bk horizon in individual paleosols from drill cores, and in accordance with the work of Breecker et al. $(2009,2010)$, we use an $S(z)$ value of $3000 \pm$ $1000 \mathrm{ppm}$ for all $p \mathrm{CO}_{2}$ estimates. This gives a final $p \mathrm{CO}_{2}$ range that is indistinguishable from the error that would result from systematic use of the empirical depth to carbonate relationship, or other methods of individually refining $S(z)$ (Cotton and Sheldon, 2012). Note that our approach to approximating $S(z)$ is essentially the same as that evaluated by Cotton and Sheldon (2012), only differing in that $S(z)$ is not estimated independently for each soil profile. As discussed herein, our $S(z)$ values give $p \mathrm{CO}_{2}$ estimates that are consistently within $\sim 500 \mathrm{ppm}$ of the independent $p \mathrm{CO}_{2}$ values output by the GEOCLIM model.

The \pm range bracketing the final $p \mathrm{CO}_{2}$ estimates reported is based on the PBUQ error estimation scheme developed by Breecker (2013), where error is approximated using Monte Carlo simulation and the error associated with each parameter. This method specifically accounts for the balance of $\mathrm{CO}_{2}$ mixtures (atmosphere vs. soil $\mathrm{CO}_{2}$ ) in assessing the formal error, and we point out that Breecker (2013) used soils from Schaller et al. (2011) as models for balanced mixtures where relative error may be reduced to a minimum. Breecker (2013, p. 3210) further noted that, "Currently, calcic paleosols are best used to test the significance of trends and/or differences among time slices in paleoatmospheric $\mathrm{CO}_{2}$ concentration."

A combination of thin sections and polished slabs was used to identify primary micritic calcite from diagenetic material (Driese and Mora, 2002), with a sampling preference for small, isolated carbonate nodules (Schaller et al., 2011). Great care was taken to avoid phreatic calcretes, and to sample only those nodules with 
first-generation micrite, following the methodology advocated by Rasbury et al. (2006). The $\delta^{13} \mathrm{C}$ value of pedogenic carbonate is known to decrease predictably with soil depth (Quade et al., 1989), and characterizing this trend makes it possible to differentiate between the relative influences of the atmospheric versus soilrespired $\mathrm{CO}_{2}$ reservoirs. Therefore, multiple (at least 5) down-profile isotopic measurements were made on each paleosol to identify an equilibrium $\delta_{\mathrm{cc}}$ value with depth in the soil (Fig. 3) (Schaller et al., 2011, 2012), rather than simply relying on measurements made on carbonates $>50 \mathrm{~cm}$ below the soil surface (Cleveland et al., 2008; Ekart et al., 1999). Using the mean of values from depths where there is no further change in $\delta_{\mathrm{cc}}$ ensures that the mixing between the atmospheric and soil-respired reservoirs is at equilibrium with respect to the diffusion model, removing significant uncertainty in assessing the isotopic equilibrium of a given paleosol profile.

Samples for organic carbon isotope analysis were taken from as close to the soil surface as possible, to avoid sampling recalcitrant organic matter that is unrelated to the organic carbon pool during soil formation (Nadelhoffer and Fry, 1988). Sampling was done with a preference for organic matter included within carbonate nodules used for $\delta_{\mathrm{cc}}$ measurement. There is disagreement within the paleosol community on the soil organic matter that should be used in calculating atmospheric $\mathrm{CO}_{2}$ (cf. Breecker, 2013; Montañez, 2013), and the degree to which degradation affects the calculated result. It is beyond the scope of this paper to address these issues, but we note that there is room for

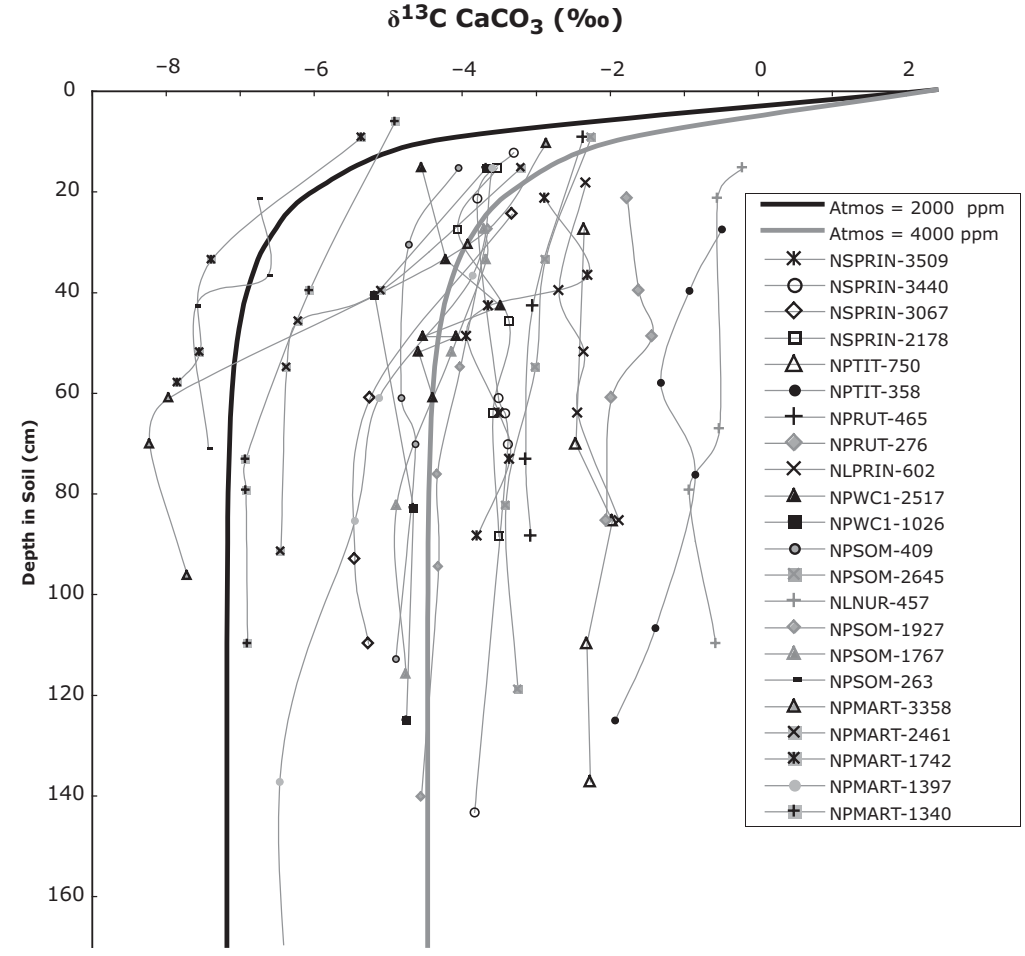

Figure 3. Down-profile $\delta^{13} \mathrm{C}$ of pedogenic carbonates $\left(\delta_{\mathrm{cc}}\right)$ from selected soils in the Newark Basin Coring Project (NBCP) composite section. Only the mean of the equilibrium $\delta_{\mathrm{cc}}$ values was used to calculate $p \mathrm{CO}_{2}$ in this study. Observed $\delta_{\mathrm{cc}}$ is compared to the $\boldsymbol{\delta}_{\mathrm{cc}}$ values predicted by the diffusion model at atmospheric $\mathrm{CO}_{2}$ concentrations of $2000 \mathrm{ppm}$ (black line) and 4000 ppm (gray line) (after Quade et al., 1989). For demonstration here only, atmospheric $\delta^{13} \mathrm{CO}_{2}$ was set to $-6.5 \%$, and soil $\delta^{13} \mathrm{C}_{\text {org }}$ was set to $-26.5 \%$, with an exponential production function and characteristic depth of production at $15 \mathrm{~cm}$ (other parameters described in text). For all $\mathrm{pCO}_{2}$ estimates made in this study, the $\delta^{13} C_{\text {org }}$ was measured directly and used as a model input. Soil carbonate above $20 \mathrm{~cm}$ in the profile was rare, but these values should not be confused with depth to the Bk horizon, which is often much deeper (Newark mean depth to $\mathrm{Bk}=\mathbf{4 0} \pm \mathbf{1 5} \mathrm{cm}$ ); note that stabilization of measured $\delta_{\mathrm{cc}}$ is commonly well below $50 \mathrm{~cm}$ soil depth. improvement of the model in this regard. Further, it has been suggested that the difference between $\delta^{13} \mathrm{C}_{\mathrm{cc}}$ and $\delta^{13} \mathrm{C}_{\text {org }}\left(\Delta \delta^{13} \mathrm{C}\right)$ should be within the range of $\sim 14 \%$ - $17 \%$ (Cotton and Sheldon, 2012; Montañez, 2013). This is an important empirical constraint on modern soils under current atmospheric conditions, but it lacks a sound theoretical basis for being maintained during other time periods. In fact, diffusive mixing within soils predicts a $\Delta \delta^{13} \mathrm{C}$ outside of the nominal $14 \%$ - $17 \%$ range if atmospheric $p \mathrm{CO}_{2}$ is high or if $S(z)$ is low, either of which effectively increases the relative influence of the atmospheric reservoir on soil gas, increasing $\Delta \delta^{13} \mathrm{C}$. The difference between $\delta^{13} \mathrm{C}_{\mathrm{cc}}$ and $\delta^{13} \mathrm{C}_{\mathrm{org}}$ is also a function of the $\delta^{13} \mathrm{C}$ of organic matter and the $\delta^{13} \mathrm{C}$ of the atmosphere at the time of soil formation.

All measurements of pedogenic calcite were made on a Micromass Optima dual-inlet Isotope Ratio Mass Spectrometer (IRMS) with a carbonate multiprep system in the Rutgers Stable Isotope Laboratory. Samples were reacted to completion with phosphoric acid in individual vials at $90{ }^{\circ} \mathrm{C}$ and analyzed against an in-house carbonate standard (RGF1) that is frequently checked against NBS19; $1 \sigma$ analytical precision is $0.05 \%$. All organic carbon $\delta^{13} \mathrm{C}$ analyses were made on a VG Isoprime continuous-flow IRMS connected to a Eurovector Elemental Analyzer. Individual organic matter samples were reacted with $25 \% \mathrm{HCl}$ to remove all carbonate, washed in distilled $\mathrm{H}_{2} \mathrm{O}$, and placed in tin capsules, which were combusted at $1200{ }^{\circ} \mathrm{C}$ and passed through a gas chromatograph (GC) column before being introduced to the mass spectrometer. An in-house standard reference material and the NBS22 standard were analyzed in each sample run, with $1 \sigma$ analytical error of $0.12 \%$.

\section{RESULTS}

From the base of the NBCP composite section (4400 $\mathrm{m}$ section depth) in the Stockton Formation, profile-equilibrated mean $\delta^{13} \mathrm{C}$ values of pedogenic carbonates are around $-6.5 \%$, increasing gradually up section to $\sim-2 \%$ by $\sim 2700 \mathrm{~m}$ section depth in the more sparsely sampled Lockatong Formation (Fig. 4). The Lockatong is composed primarily of deeper lacustrine facies, and suitable paleosols are rare here because the NBCP cores were taken to preferentially recover the deepest portion of the Newark rift lake. The Lockatong Formation maximum in carbonate $\delta^{13} \mathrm{C}$ is followed by a generally decreasing trend toward $-7 \%$ at the top of the Passaic Formation (Fig. 4), just below the first flow unit of the Central Atlantic magmatic province. The $\delta^{13} \mathrm{C}$ of soil organic matter 


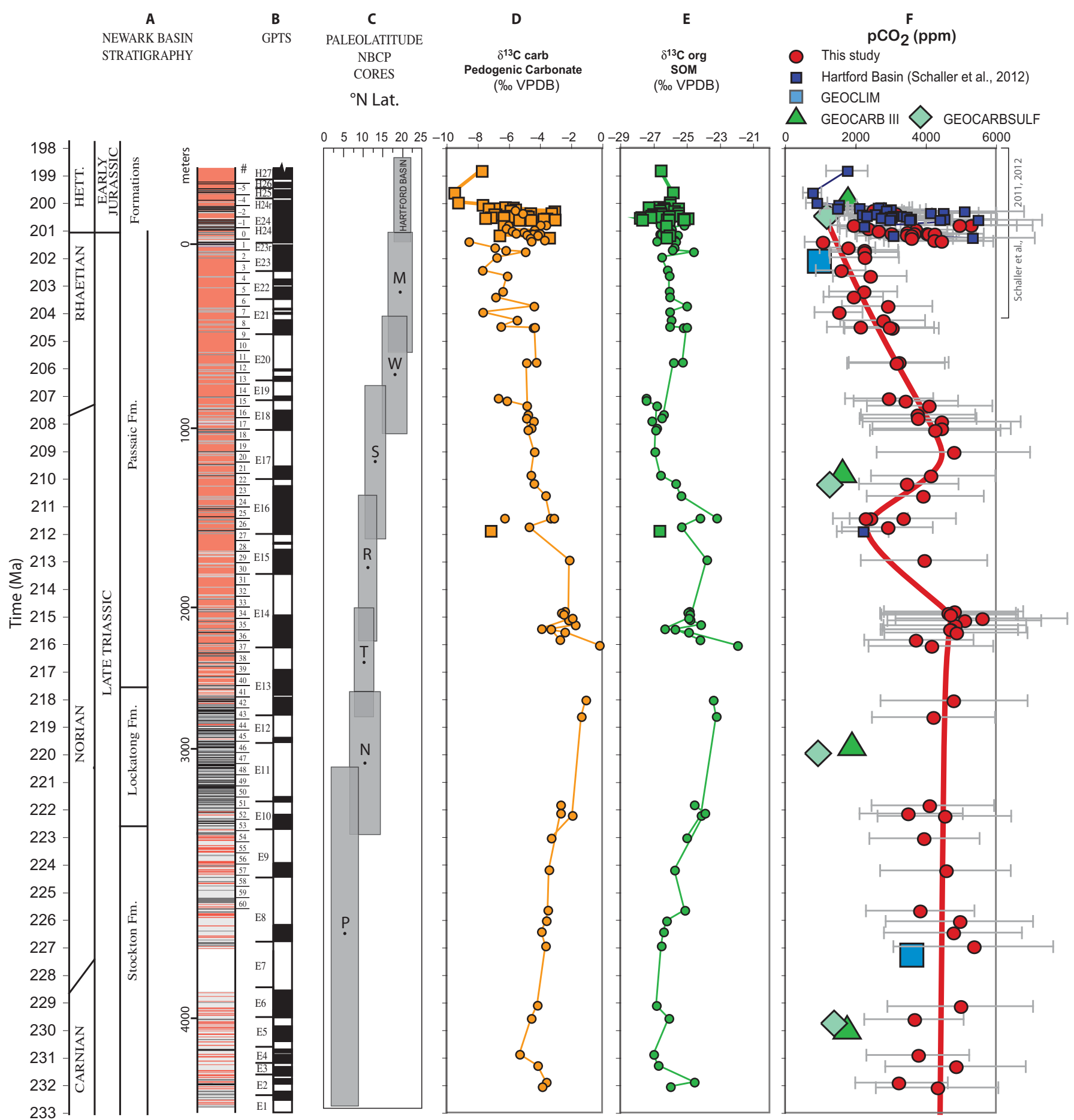

Figure 4. (A) Newark and Hartford Basin composite chronostratigraphy and lithology from Olsen et al. (2011). (B) Geomagnetic polarity time scale (GPTS); filled (normal polarity) and open (reversed polarity) bars are chrons from Kent and Olsen (1999). (C) Mean paleolatitudes corrected for inclination flattening from Newark Basin Coring Project (NBCP) cores (Kent and Tauxe [2005]) and Hartford Basin outcrop (Kent and Olsen, 2008). M-Martinsville, W-Weston Canal, S-Somerset, R-Rutgers, T-Titusville, N-Nursury, P-Princeton. (D) Equilibrium $\delta^{13} \mathrm{C}$ of pedogenic carbonates from NBCP cores shown as circles connected by lines corresponding to individual cores. Squares represent data from the Hartford Basin (Schaller et al., 2012). VPDB-Vienna Peedee belemnite. (E) $\delta^{13} \mathrm{C}$ of organic matter; symbols and lines as in D. (F) $\mathrm{pCO}_{2}$ calculated from $\mathrm{D}$ and $\mathrm{E}$ using Equation 1. Red circles are $\mathrm{pCO}_{2}$ values with gray error bars calculated using PBUQ (Breecker, 2013), red line placed by eye. Model output of GEOCARB III (Berner and Kothavala, 2001) (dk. green triangles), GEOCARBSULF (Berner, 2006) (It. green diamonds), and GEOCLIM (Goddéris et al., 2008) (blue squares). Bracketed section of pCO $\mathrm{CO}_{2}$ data shown in blue circles is from Schaller et al. (2011; and 2012) and attributed to perturbations due to the eruption of the Central Atlantic magmatic province. Note closely clustered $\mathrm{pCO}_{2}$ values calculated from samples in stratigraphic overlap in the Titusville and Rutgers cores, which are situated $\sim 50 \mathrm{~km}$ apart. 
generally parallels that of pedogenic carbonate through the $\sim 6000 \mathrm{~m}$ of section, with values around $-27 \%$ at the base of the section, increasing to $-23 \%$ in the Lockatong, followed by a gradual decrease (with variability) through the Passaic Formation. The measured isotope values (and calculated atmospheric $\mathrm{CO}_{2}$ concentrations) show excellent reproducibility, even in the $200 \mathrm{~m}$ interval of overlap between the widely separated Rutgers and Titusville cores (Table 1). The $\delta^{13} \mathrm{C}$ of atmospheric $\mathrm{CO}_{2}$ calculated using Equation 3 gives values mainly between $-4 \%$ and $-7 \%$, which are very close to what would be calculated from a systematic mean of marine carbonates, and very close to the mean of mantle-derived carbon (for review, see Shirey et al., 2013).

The thick continuous continental section preserved in the Newark Basin provides a continuous record of $p \mathrm{CO}_{2}$ for roughly $33 \mathrm{Myr}$ from the Late Triassic Carnian to the earliest Jurassic Hettangian. In the broadest chronostratigraphic sense, $p \mathrm{CO}_{2}$ calculated from detailed isotope measurements on these paleosols follows an overall decreasing trend from $\sim 4500 \pm 1900 \mathrm{ppm}$ at around $228 \mathrm{Ma}$ in the late Carnian to $\sim 2000 \pm 800 \mathrm{ppm}$ at around 202 $\mathrm{Ma}$ in the latest Rhaetian, with several notable variations (Fig. 4). From 232 to $215 \mathrm{Ma}, p \mathrm{CO}_{2}$ remains relatively constant at around $\sim 4400 \pm$ $1800 \mathrm{ppm}$, and then at $215 \mathrm{Ma}$, we observe a secular decrease over 4 Myr to a local minimum of $\sim 2000 \pm 800 \mathrm{ppm}$ at ca. $211 \mathrm{Ma}$. Comparably low atmospheric $p \mathrm{CO}_{2}$ is also found at this age-correlative level $250 \mathrm{~km}$ to the north in the Hartford Basin (Schaller et al., 2012) from exposures in the New Haven Formation dated to $\mathrm{ca} .211 .9 \pm 2.1 \mathrm{Ma}$ by $\mathrm{U}-\mathrm{Pb}$ on pedogenic calcretes (Wang et al., 1998). A 3 Myr increase culminating in a $p \mathrm{CO}_{2}$ maximum at $209 \mathrm{Ma}$ of $4500 \pm 1400 \mathrm{ppm}$ is followed by an $8 \mathrm{Myr} \mathrm{sec}-$ ular decrease to $\sim 1100 \mathrm{ppm}$ to just before the Central Atlantic Magmatic Province (CAMP) eruptions. Rapid $p \mathrm{CO}_{2}$ perturbations are observed in stratigraphic superposition above each of the CAMP flow units (in both the Newark and Hartford Basins; Figs. 4 and 5) and are attributed to the emplacement of the Central Atlantic large igneous province (Schaller et al., 2011). Because fresh basalts weather (and consume $\mathrm{CO}_{2}$ ) at a rate roughly 10 times that of continental crust (Dessert et al., 2003), the rapid falloff in $p \mathrm{CO}_{2}$ following each of these transient increases is a predicted consequence of this massive, rapidly emplaced continental flood basalt complex straddling the equatorial humid belt (Schaller et al., 2012). The net effect is that $p \mathrm{CO}_{2}$ falls to below pre-eruptive background concentrations in less than 300 k.y. following the final episode of eruption.

\section{Comparison with Other Triassic $\mathrm{pCO}_{2}$ Estimates}

The tight age control provided by the Newark Basin cycle and magnetic stratigraphy combined with precise radiometric ages on the Central Atlantic magmatic province basalts (Blackburn et al., 2013) provide a template for comparing paleosol-based $p \mathrm{CO}_{2}$ estimates and stomata-based reconstructions assembled from widely separated sections spanning the same $\sim 30$ Myr interval (Fig. 2), though there is significant uncertainty in correlating these sparse, and generally short-duration data sets. Our $p \mathrm{CO}_{2}$ observations are consistent with the longterm decreasing trend over the Late Triassic in $p \mathrm{CO}_{2}$ estimates from plant stomata, with values as high as $\sim 3700 \mathrm{ppm}$ in the Carnian, falling to $\sim 1000$ ppm in the Rhaetian (Fig. 5; McElwain et al., 1999; Retallack, 2001). Stomata-based $p \mathrm{CO}_{2}$ estimates tend to be lower than those made from pedogenic carbonates, particularly because the stomatal index proxy tends to saturate at values as low as $\sim 1200 \mathrm{ppm}$ (Beerling and Royer, 2002b), although stomatal ratios are apparently able to detect higher values (e.g., Retallack, 2001; Steinthorsdottir et al., 2011). Even so, the relative changes in both stomatabased $p \mathrm{CO}_{2}$ estimates and those from pedogenic carbonates often parallel one another, indicating that they are tracking the same signal, as is the case in the Central Atlantic magmatic province interval (see Schaller et al., 2011).

Much of the older paleosol data often lacked paired organic-inorganic $\delta^{13} \mathrm{C}$ analyses, or multiple down-profile carbon isotope measurements were not made (e.g., Ekart et al., 1999; Suchecki et al., 1988; Tanner et al., 2001). However, with these caveats in mind, these lower-resolution studies show trends that are generally similar to our observations in the Newark basin, though the absolute values and stratigraphic alignment are subject to significant uncertainty (Fig. 5). More detailed work on the Late Triassic Chinle section by Cleveland et al. (2008) can be aligned with the Newark chronostratigraphy more precisely. A detrital zircon date places the base of the Ghost Ranch section at 211.9 $\pm 0.07 \mathrm{Ma}$ (Irmis et al., 2011), making the low $\mathrm{pCO}_{2}$ estimates of Cleveland et al. (2008) for this section comparable to the $p \mathrm{CO}_{2}$ minimum around $212 \mathrm{Ma}$ in the Newark Basin section. The gradual increasing $p \mathrm{CO}_{2}$ trend from $\sim 500 \mathrm{ppm}$ to $3700 \mathrm{ppm}$ between 212 and 209 Ma in Cleveland et al.'s reconstruction is remarkably similar to the $\sim 1800-4000$ ppm increase observed over the same inferred interval in the Newark section. The difference in absolute value between these two sections is most likely due to Cleveland et al.'s (2008) use of a uniform $\delta^{13} \mathrm{C}_{\text {org }}$, which is based on the average of two measurements made on preserved charcoal from the Ghost Ranch locality, with an average value of $-23.5 \%$. This mean value may not be representative of all the variability in $\delta^{13} \mathrm{C}_{\text {org }}$ from these sections, and hence a more detailed characterization with $\delta^{13} \mathrm{C}_{\text {org }}$ measurements from each soil is necessary. If a more primary $\delta^{13} \mathrm{C}_{\text {org }}$ value (for example, $-26.5 \%$ o) is substituted, the resulting $p \mathrm{CO}_{2}$ estimates are better aligned with our observations in the Newark section, even though an anomalously low $\mathrm{CO}_{2}$ level of $\sim 25 \mathrm{ppm}$ reported by Cleveland et al. (2008) in the lowest part of the Ghost Ranch section is very difficult to understand. For reference, the threshold for Antarctic glaciation in the earliest Oligocene has been estimated at 750 ppm (DeConto et al., 2008).

We note that the general trend of increasing apparent aridity of facies up section in the Newark Basin, from the Lockatong to the Passaic Formations (Smoot, 1991), would tend to favor soils with lower $S(z)$ values because of decreased soil productivity and increased seasonal extremes (Breecker et al., 2009). If this were the case, our use of a fixed $S(z)$ biases our results from the upper part of the section toward higher calculated $p \mathrm{CO}_{2}$ values. Indeed, a hypothetical decreasing trend in $S(z)$ with increasing aridity up section would intensify the observed decrease in $\mathrm{pCO}_{2}$, reflecting the reduced influence of the isotopically light, soil-respired $\mathrm{CO}_{2}$ reservoir on soil $\mathrm{CO}_{2}$. Instead, our $p \mathrm{CO}_{2}$ estimates decrease up section, despite our uniform parameterization of $S(z)$.

\section{PANGEA'S NORTHWARD DRIFT CREATES A MASSIVE CONTINENTAL SINK FOR $\mathrm{CO}_{2}$}

The most compelling feature of the Newark Basin $p \mathrm{CO}_{2}$ record is the long-term decrease from $\sim 4500 \mathrm{ppm}$ in the late Carnian to $2000 \mathrm{ppm}$ in the late Rhaetian (Fig. 4). Mass-balance models such as GEOCARB III/GEOCARBSULF (Berner, 2006; Berner and Kothavala, 2001) or COPSE (Bergman et al., 2004), based on the BLAG hypothesis (Berner et al., 1983), do not show this approximately threefold $\mathrm{pCO}_{2}$ decrease in the Late Triassic (Fig. 4). "Zerodimensional" models like GEOCARB do not have spatially resolved climate and therefore use a planetary mean approach to geographically induced changes in weathering rates, which are incorporated by making adjustments to the global weathering feedback term. Instead, the major forcing of $p \mathrm{CO}_{2}$ change in these models is from the cumulative effects of changes in crustal production rate and accompanying $\mathrm{CO}_{2}$ degassing, which are approximated over pre- 
TABLE 1. SAMPLES, ANALYTICAL RESULTS, AND CALCULATED $p \mathrm{CO}_{2}$

\begin{tabular}{|c|c|c|c|c|c|c|c|c|c|c|c|}
\hline \multirow[b]{2}{*}{ Sample } & \multicolumn{2}{|c|}{ Core or outcrop } & \multirow[b]{2}{*}{ NBCP core } & \multirow[b]{2}{*}{ Formation } & \multirow{2}{*}{$\begin{array}{c}\text { Depth below } \\
\text { OMB base } \\
(\mathrm{m})\end{array}$} & \multirow[b]{2}{*}{$\begin{array}{c}\text { Age } \\
(\mathrm{Ma})^{\dagger}\end{array}$} & \multirow{2}{*}{$\begin{array}{c}\text { Down-profile } \\
\text { mean } \delta^{13} C_{c c} \\
(\% \circ P D B)\end{array}$} & \multirow[b]{2}{*}{$\begin{array}{c}\delta^{13} \mathrm{C}_{\text {org }} \\
(\% \circ \mathrm{PDB})\end{array}$} & \multirow[b]{2}{*}{$\begin{array}{c}\delta^{13} \mathrm{C}_{\text {ATM }} \\
(\% \circ \mathrm{PDB})^{\S}\end{array}$} & \multirow[b]{2}{*}{$\begin{array}{l}p \mathrm{CO}_{2} \\
(\mathrm{ppm})\end{array}$} & \multirow[b]{2}{*}{$\begin{array}{l}\text { Error } \pm \\
(p p m)^{\#}\end{array}$} \\
\hline & $\begin{array}{l}\text { Lat } \\
\left({ }^{\circ} \mathrm{N}\right)\end{array}$ & $\begin{array}{l}\text { Long } \\
\left({ }^{\circ} \mathrm{W}\right)\end{array}$ & & & & & & & & & \\
\hline Orange Mt. Basalt & & & & & & 201.52 & & & & & \\
\hline NPEX* & 40.31323 & 75.84327 & Outcrop & Passaic & 15.27 & 201.54 & -8.58 & -25.67 & -6.4 & 1065 & 392.1 \\
\hline NPMART-1340* & 40.6317 & 74.6033 & Martinsville & Passaic & 119.22 & 201.76 & -6.91 & -25.75 & -6.4 & 1784.4 & 690.0 \\
\hline NPMART-1397* & 40.6317 & 74.6033 & Martinsville & Passaic & 139.73 & 201.84 & -6.20 & -25.86 & -6.5 & 2242.1 & 875.4 \\
\hline NPC87-377* & 40.8735 & 74.2007 & ACE C-87 & Passaic & 159.23 & 201.91 & -4.96 & -24.59 & -5.4 & 2253 & 877.0 \\
\hline NPMART-1649* & 40.6317 & 74.6033 & Martinsville & Passaic & 166.53 & 202.10 & -6.78 & -26.50 & -7.1 & 2263.3 & 875.3 \\
\hline NPMART-1743* & 40.6317 & 74.6033 & Martinsville & Passaic & 175.85 & 202.58 & -7.70 & -26.16 & -6.8 & 1596.8 & 604.4 \\
\hline NPMART-2055* & 40.6317 & 74.6033 & Martinsville & Passaic & 210.15 & 202.78 & -6.11 & -26.06 & -6.7 & 2419.9 & 946.7 \\
\hline NPMART-2462* & 40.6317 & 74.6033 & Martinsville & Passaic & 303.78 & 203.34 & -6.41 & -26.06 & -6.7 & 2230.2 & 869.3 \\
\hline NPMART-2582* & 40.6317 & 74.6033 & Martinsville & Passaic & 336.70 & 203.54 & -6.87 & -26.02 & -6.7 & 1946.8 & 745.4 \\
\hline NPMART-2799 & 40.6317 & 74.6033 & Martinsville & Passaic & 391.86 & 203.87 & -4.41 & -25.01 & -5.8 & 2913.8 & 1181.9 \\
\hline $\mathrm{NPOO}^{*}$ & 40.29398 & 75.83817 & Outcrop & Passaic & 428.20 & 204.09 & -7.68 & -26.02 & -6.7 & 1532 & 584.2 \\
\hline NPMART-3143* & 40.6317 & 74.6033 & Martinsville & Passaic & 477.85 & 204.39 & -5.47 & -25.94 & -6.6 & 2781.7 & 1098 \\
\hline NPMART-3358* & 40.6317 & 74.6033 & Martinsville & Passaic & 516.52 & 204.62 & -6.53 & -26.03 & -6.7 & 2140.7 & 833.2 \\
\hline NPMART-3400 & 40.5883 & 74.6317 & Weston Canal 2 & Passaic & 520.70 & 204.64 & -4.34 & -25.00 & -5.8 & 2960.0 & 1082.7 \\
\hline NPWC2-253 & 40.6317 & 74.6033 & Martinsville & Passaic & 523.67 & 204.66 & -4.44 & -25.20 & -5.9 & 3035.7 & 1131.2 \\
\hline NPWC1-1011 & 40.5883 & 74.6317 & Weston Canal 1 & Passaic & 731.34 & 205.91 & -4.25 & -25.26 & -6.0 & 3236.8 & 1210.0 \\
\hline NPWC1-1026 & 40.5883 & 74.6317 & Weston Canal 1 & Passaic & 735.27 & 205.93 & -4.87 & -25.81 & -6.5 & 3155.8 & 1180.8 \\
\hline NPWC1-2220 & 40.5517 & 74.6467 & Somerset 1 & Passaic & 950.22 & 207.22 & -6.69 & -27.44 & -8.0 & 2944.2 & 1075.7 \\
\hline NPWC1-2301 & 40.5517 & 74.6467 & Somerset 1 & Passaic & 964.33 & 207.31 & -6.13 & -27.44 & -8.0 & 3413.4 & 1305.6 \\
\hline NPWC1-2368 & 40.5517 & 74.6467 & Somerset 1 & Passaic & 995.00 & 207.49 & -4.86 & -26.81 & -7.4 & 4085.6 & 1600.0 \\
\hline NPWC1-2517 & 40.5883 & 74.6317 & Weston Canal 1 & Passaic & 1048.44 & 207.81 & -4.78 & -26.40 & -7.0 & 3758.0 & 1449.3 \\
\hline NPSOM-263 & 40.5883 & 74.6317 & Weston Canal 1 & Passaic & 1070.32 & 207.94 & -4.87 & -26.50 & -7.1 & 3762.6 & 1483.5 \\
\hline NPSOM-309 & 40.5883 & 74.6317 & Weston Canal 1 & Passaic & 1088.62 & 208.05 & -4.43 & -27.10 & -7.7 & 4429.7 & 2067.3 \\
\hline NPSOM-409 & 40.5883 & 74.6317 & Weston Canal 1 & Passaic & 1130.34 & 208.30 & -4.55 & -26.80 & -7.4 & 4429.7 & 1783.7 \\
\hline NPSOM-904 & 40.5517 & 74.6467 & Somerset 1 & Passaic & 1141.55 & 208.37 & -4.79 & -26.88 & -7.5 & 4247.6 & 1677.8 \\
\hline NPSOM-1350 & 40.5517 & 74.6467 & Somerset 1 & Passaic & 1273.46 & 209.16 & -4.38 & -26.91 & -7.5 & 4786.6 & 1970.0 \\
\hline NPSOM-1767 & 40.5517 & 74.6467 & Somerset 1 & Passaic & 1415.54 & 210.01 & -4.59 & -26.57 & -7.2 & 4134.0 & 1638.1 \\
\hline NPSOM-1927 & 40.5517 & 74.6467 & Somerset 1 & Passaic & 1465.20 & 210.31 & -4.40 & -25.66 & -6.4 & 3443.3 & 1287.8 \\
\hline NPSOM-2214 & 40.5517 & 74.6467 & Somerset 1 & Passaic & 1538.84 & 210.75 & -3.64 & -25.36 & -6.1 & 3908.4 & 1539.6 \\
\hline NPSOM-2645 & 40.5517 & 74.6467 & Somerset 1 & Passaic & 1673.81 & 211.56 & -3.33 & -23.19 & -4.1 & 2435.1 & 864.7 \\
\hline NPRUT2-465 & 40.5883 & 74.4333 & Rutgers 2 & Passaic & 1674.25 & 211.57 & -3.11 & -24.20 & -5.0 & 3354.9 & 1304.8 \\
\hline NPRUT-619 & 40.5883 & 74.4333 & Rutgers 1 & Passaic & 1727.99 & 211.89 & -4.71 & -25.33 & -6.1 & 2913.4 & 1083.0 \\
\hline NPRUT-1254 & 40.5883 & 74.4333 & Rutgers 1 & Passaic & 1927.27 & 213.08 & -2.12 & -23.80 & -4.7 & 3953.4 & 1591.8 \\
\hline NPRUT-2597 & 40.3750 & 74.8533 & Titusville 1 & Passaic & 2237.87 & 214.95 & -2.42 & -24.84 & -5.6 & 4791.5 & 1982.5 \\
\hline NPRUT-2710 & 40.3750 & 74.8533 & Titusville 1 & Passaic & 2246.50 & 215.00 & -2.63 & -24.93 & -5.7 & 4631.7 & 1927.9 \\
\hline NPRUT-2808 & 40.3750 & 74.8533 & Titusville 1 & Passaic & 2256.90 & 215.06 & -2.48 & -24.82 & -5.6 & 4684.8 & 1945.1 \\
\hline NPRUT-3082 & 40.3750 & 74.8533 & Titusville 1 & Passaic & 2279.07 & 215.19 & -1.94 & -24.89 & -5.7 & 5583.6 & 2441.0 \\
\hline NPTIT-148 & 40.5883 & 74.4333 & Rutgers 1 & Passaic & 2290.27 & 215.26 & -2.17 & -24.80 & -5.6 & 5093.6 & 2185.3 \\
\hline NPTIT-192 & 40.5883 & 74.4333 & Rutgers 1 & Passaic & 2320.08 & 215.44 & -1.74 & -24.15 & -5.0 & 4827.1 & 2026.2 \\
\hline NPTIT-245 & 40.3750 & 74.8533 & Titusville 1 & Passaic & 2343.60 & 215.58 & -3.91 & -26.32 & -7.0 & 4670.4 & 1958.2 \\
\hline NPTIT-358 & 40.5883 & 74.4333 & Rutgers 1 & Passaic & 2345.93 & 215.60 & -3.32 & -25.72 & -6.4 & 4698.5 & 1931.9 \\
\hline NPTIT-652 & 40.3750 & 74.8533 & Titusville 1 & Passaic & 2363.68 & 215.70 & -2.41 & -24.88 & -5.6 & 4860.9 & 2035.3 \\
\hline NPTIT-750 & 40.5883 & 74.4333 & Rutgers 1 & Passaic & 2409.72 & 215.98 & -2.74 & -24.20 & -5.0 & 3705.3 & 1448.3 \\
\hline NPTIT-1174 & 40.3750 & 74.8533 & Titusville 1 & Passaic & 2444.37 & 216.19 & -0.19 & -21.95 & -3.0 & 4150.5 & 1776.9 \\
\hline NLNUR-457 & 40.3050 & 74.8617 & Nursery 1 & Lockatong & 2774.80 & 218.17 & -1.07 & -23.40 & -4.3 & 4774.9 & 2066.5 \\
\hline NLNUR-837 & 40.3050 & 74.8617 & Nursery 1 & Lockatong & 2874.10 & 218.76 & -1.35 & -23.22 & -4.1 & 4198.0 & 1727.1 \\
\hline NLNUR-2959 & 40.3817 & 74.6817 & Princeton & Lockatong & 3407.98 & 221.97 & -2.69 & -24.54 & -5.3 & 4098.1 & 1644.1 \\
\hline NSNUR-3302 & 40.3817 & 74.6817 & Princeton & Lockatong & 3457.69 & 222.27 & -2.68 & -23.90 & -4.8 & 3487.4 & 1368.1 \\
\hline NLPRIN-602 & 40.3050 & 74.8617 & Nursery 1 & Lockatong & 3471.47 & 222.35 & -1.94 & -24.13 & -5.0 & 4534.0 & 1900.5 \\
\hline NLPRIN-749 & 40.3050 & 74.8617 & Nursery 1 & Stockton & 3608.32 & 223.17 & -3.27 & -25.00 & -5.8 & 3941.0 & 1546.6 \\
\hline NSPRIN-1391 & 40.3817 & 74.6817 & Princeton & Stockton & 3801.40 & 224.33 & -3.44 & -25.74 & -6.4 & 4563.1 & 1855.4 \\
\hline NSPRIN-1779 & 40.3817 & 74.6817 & Princeton & Stockton & 4045.40 & 225.79 & -3.51 & -25.13 & -5.9 & 3821.2 & 1515.2 \\
\hline NSPRIN-1897 & 40.3817 & 74.6817 & Princeton & Stockton & 4108.68 & 226.17 & -3.60 & -26.22 & -6.9 & 4953.6 & 2095.1 \\
\hline NSPRIN-2021 & 40.3817 & 74.6817 & Princeton & Stockton & 4176.01 & 226.58 & -3.90 & -26.40 & -7.0 & 4773.9 & 1961.9 \\
\hline NSPRIN-2178 & 40.3817 & 74.6817 & Princeton & Stockton & 4261.27 & 227.09 & -3.64 & -26.54 & -7.2 & 5352.2 & 2270.0 \\
\hline NSPRIN-2409 & 40.3817 & 74.6817 & Princeton & Stockton & 4620.96 & 229.25 & -4.17 & -26.84 & -7.4 & 4979.6 & 2076.1 \\
\hline NSPRIN-2585 & 40.3817 & 74.6817 & Princeton & Stockton & 4700.05 & 229.72 & -4.56 & -26.07 & -6.7 & 3668.4 & 1411.6 \\
\hline NSPRIN-3067 & 40.3817 & 74.6817 & Princeton & Stockton & 4916.63 & 231.02 & -5.32 & -26.98 & -7.6 & 3774.6 & 1463.1 \\
\hline NSPRIN-3217 & 40.3817 & 74.6817 & Princeton & Stockton & 4984.03 & 231.42 & -4.16 & -26.72 & -7.3 & 4846.3 & 1996.7 \\
\hline NSPRIN-3440 & 40.3817 & 74.6817 & Princeton & Stockton & 5084.23 & 232.03 & -3.59 & -24.54 & -5.3 & 3214.2 & 1211.0 \\
\hline NSPRIN-3509 & 40.3817 & 74.6817 & Princeton & Stockton & 5112.46 & 232.19 & -3.87 & -25.98 & -6.6 & 4326.3 & 1740.6 \\
\hline
\end{tabular}

Note: NBCP—Newark Basin Coring Project; OMB-Orange Mountain Basalt; PDB-Peedee belemnite standard

*Samples/values from Schaller et al. (2011)

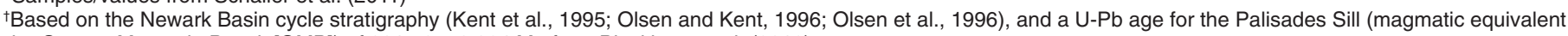
to the Orange Mountain Basalt [OMB]) of $201.52 \pm 0.034$ Ma from Blackburn et al. (2013).

$\S$ The $\delta^{13} \mathrm{C}$ of atmospheric $\mathrm{CO}_{2}$ is calculated from the $\delta^{13} \mathrm{C}$ of soil organic matter following Equation 3 (Arens et al., 2000).

\#Error on the $\mathrm{pCO}_{2}$ estimate was assigned via Monte Carlo simulation using the PBUQ program provided by Breecker (2013). 
Jurassic time scales by inverting long-term sea-level reconstructions (e.g., Gaffin, 1987). However, the sea-level-based record of ocean crust production used in the GEOCARB models shows very little change during the Late Triassic (Gaffin, 1987), meaning there is virtually no $p \mathrm{CO}_{2}$ forcing incorporated in the model. Consequently, the model produces a quasi-steadystate result (see Fig. 4) wherein the remaining second-order terms (e.g., burial of organic carbon) become the only potentially discernible influences over $p \mathrm{CO}_{2}$ in the model.

Because the organic carbon cycle is responsible for $\sim 20 \%$ of Earth's readily exchangeable carbon (Berner, 1990), the second-order changes in $p \mathrm{CO}_{2}$ could reflect variations in the rate of organic carbon burial or exhumation. Those should be apparent from the $\delta^{13} \mathrm{C}$ of coeval marine carbonate. The only systematic change observed in the Tethys marine $\delta^{13} \mathrm{C}$ record through this interval is a long-term $\delta^{13} \mathrm{C}$ decrease from ca. $227 \mathrm{Ma}$ to ca. $210 \mathrm{Ma}$ (Fig. 5; Korte et al., 2005; Muttoni et al., 2014). This trend would suggest a decrease in organic matter burial, which should correspond to an increase in $p \mathrm{CO}_{2}$ through the interval, at odds with our observations of stable to decreasing $p \mathrm{CO}_{2}$. However, the $\sim 2 \%$ fall in marine $\delta^{13} \mathrm{C}$ between ca. 216 and $205 \mathrm{Ma}$ is coincident with an $\sim 2 \%$ o decrease in the $\delta^{13} \mathrm{C}$ of soil organic matter, indicating that the $\delta^{13} \mathrm{C}$ of atmospheric $\mathrm{CO}_{2}$ $\left(\delta^{13} \mathrm{C}_{\text {atm }}\right)$ is being closely tracked by the terrestrial organic reservoir, and the two may be close to steady state (validating this assumption in the $p \mathrm{CO}_{2}$ calculation). Furthermore, this suggests that the degree of photosynthetic fractionation is not changing substantially, despite the large changes in $p \mathrm{CO}_{2}$ through the interval. This trend is also mimicked by the $\delta^{13} \mathrm{C}$ of soil carbonates, which decrease by $\sim 3 \%$ over the interval, i.e., $\sim 1 \%$ o more than terrestrial organic matter. A progressive decrease in soil productivity would have the opposite effect. It is important to note that the $\delta^{13} \mathrm{C}$ values of marine carbonates from restricted basins, such as the Tethys, are subject to significant regional effects (e.g., see Bachan et al., 2012) and, therefore, may not be fully representative of global changes in burial or oxidation of organic matter. Nonetheless, there is no evidence for global net oxidation of organic matter from 212 to $209 \mathrm{Ma}$, precluding that as a cause for the observed $p \mathrm{CO}_{2}$ increase over this time period.

The GEOCLIM model (Goddéris et al., 2008), which couples a carbon-cycle massbalance model to a three-dimensional (3D) climate model, predicts atmospheric $p \mathrm{CO}_{2}$ of $>3000 \mathrm{ppm}$ in the Carnian, falling to $<1000$ ppm in the Rhaetian. Unlike the simpler BLAG/ GEOCARB/COPSE mass-balance models,
GEOCLIM includes the effects of changing paleogeography while holding ocean crust production (and hence, mantle $\mathrm{CO}_{2}$ degassing) constant through the Late Triassic. The result is a threefold decrease in $p \mathrm{CO}_{2}$ between GEOCLIM model runs in the Carnian and the Rhaetian, which bracket the more continuous observed $p \mathrm{CO}_{2}$ changes in the Newark Basin record (Fig. 5). Because of Pangea's geometry, northward movement during the Late Triassic increased the amount of continental area within the equatorial humid belt (Goddéris et al., 2008), which accounts for $\sim 70 \%$ of modern silicate weathering (Gaillardet et al., 1999). This northward progression, with a long-term average of $0.6^{\circ}$ latitude/Myr based on paleolatitudes calculated from the NBCP cores (Fig. 2; Kent and Tauxe, 2005), furnished a massive continental sink for $\mathrm{CO}_{2}$.

In more detail, lithology introduced to the equatorial humid belt could be an important influence over the higher-order changes in $p \mathrm{CO}_{2}$ (Dessert et al., 2003; Kent and Muttoni, 2013; Schaller et al., 2012), such as the dip centered around ca. $212 \mathrm{Ma}$. A comparable $p \mathrm{CO}_{2}$ minimum is recorded in the Hartford Basin, in well-dated exposures $\sim 250 \mathrm{~km}$ to the north of the Newark Basin, and is also observed in the Chinle section (Fig. 5), though the absolute values differ for reasons discussed already. The cause of this $\sim 5 \mathrm{Myr}$ drop and rebound in $\mathrm{pCO}_{2}$ is unclear. Given the uncertainty in the details of Pangea's motion, and the exact surface lithology, vegetation cover, etc., we can only speculate on the source of this anomaly, making it a prime target for more detailed carbon cycle, climate, and paleogeographic modeling efforts in the future. However, it is important to note that a transient decrease in atmospheric $\mathrm{CO}_{2}$ of this magnitude can be accomplished through the introduction of fresh, highly weatherable basalts to the equatorial belt (Kent and Muttoni, 2008). Because basaltic rock weathers $\sim 10$ times faster under otherwise equal conditions (Dessert et al., 2003; Gaillardet et al., 1999), the amount of area necessary to drawdown $\mathrm{CO}_{2}$ would be roughly

10 times less. The rate of delivery of crustal rock into and out of a weathering regime may be an important additional influence over the rate of $\mathrm{CO}_{2}$ consumption, but quantifying the complex interplay between the tempo of plate motion and continental weathering rates requires a much more detailed assessment of the distribution of continental area, rates of movement, and variations in topographic relief and lithology, all within a model like GEOCLIM, but with better spatial-temporal resolution.

\section{CONCLUSIONS}

We have generated a $\sim 30 \mathrm{Myr}$ record of atmospheric $p \mathrm{CO}_{2}$ through the Late Triassic (Carnian to Rhaetian), using the carbon isotopic composition of the organic and inorganic phases of paleosols distributed throughout the very thick and cycle stratigraphically-continuous continental sediment section of the Newark rift basin. We find high $p \mathrm{CO}_{2}$ levels near $4500 \pm 1800 \mathrm{ppm}$ in the late Carnian, decreasing to $\sim 1500 \pm 600 \mathrm{ppm}$ by the latest Rhaetian, which agree with $p \mathrm{CO}_{2}$ estimates from other, albeit less detailed, sections covering this stratigraphic interval. Together, these results support the following:

(1) Our results are consistent with the GEOCLIM model results of Goddéris et al. (2008); both studies indicate a threefold reduction in atmospheric $p \mathrm{CO}_{2}$ over the Late Triassic. The parallel offset $(\sim 500 \mathrm{ppm})$ between the $p \mathrm{CO}_{2}$ estimates reported here and the model results of GEOCLIM suggests that our estimates are faithful to the character of the actual changes in atmospheric $\mathrm{CO}_{2}$ through the Late Triassic.

(2) The agreement between our empirical results and the results of GEOCLIM support the conclusions of Goddéris et al. (2008), who suggested that the Late Triassic increase in continental area within the tropical humid belt via Pangea's northward migration resulted in an increase in the consumption of $\mathrm{CO}_{2}$ by continental silicate weathering, leading to a threefold reduction in atmospheric $p \mathrm{CO}_{2}$. We can only

Figure 5 (on following page). (A) Newark and Hartford Basin $\mathrm{CCO}_{2}$ records from Figure 3F. (B) Compilation of $p \mathrm{CO}_{2}$ estimates from other sections by various methods. Orange circles are paleosol estimates from miscellaneous locales (Ekart et al., 1999; Suchecki et al., 1988; Tanner et al., 2001). Paleosol estimates from Chinle Formation of Cleveland et al. (2008) are represented by gray triangles (Montoya Section) and light-blue squares (Ghost Ranch section). Green diamonds show $\mathrm{pCO}_{2}$ estimates from plant stomata (both stomatal index and stomatal ratio) with error bars (McElwain et al., 1999; Retallack, 2001, 2009a; Steinthorsdottir et al., 2011). Gray dashed line shows the saturation threshold above which stomatal index is insensitive to changes in atmospheric $p \mathrm{CO}_{2}$ concentrations (see Beerling and Royer, 2002a, 2002b). (C) $\delta^{13} \mathrm{C}$ of marine carbonates from Tethyan sections (Katz et al., 2005; Korte et al., 2005; Muttoni et al., 2014). 
A

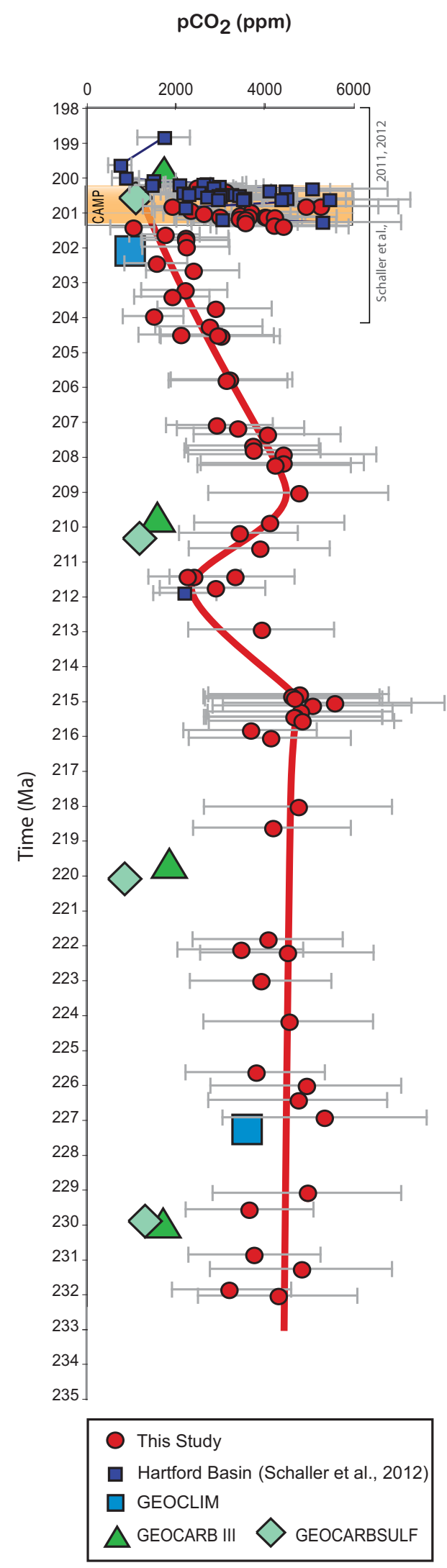

B

$\mathrm{pCO}_{2}$ Estimates from other sections (ppm)
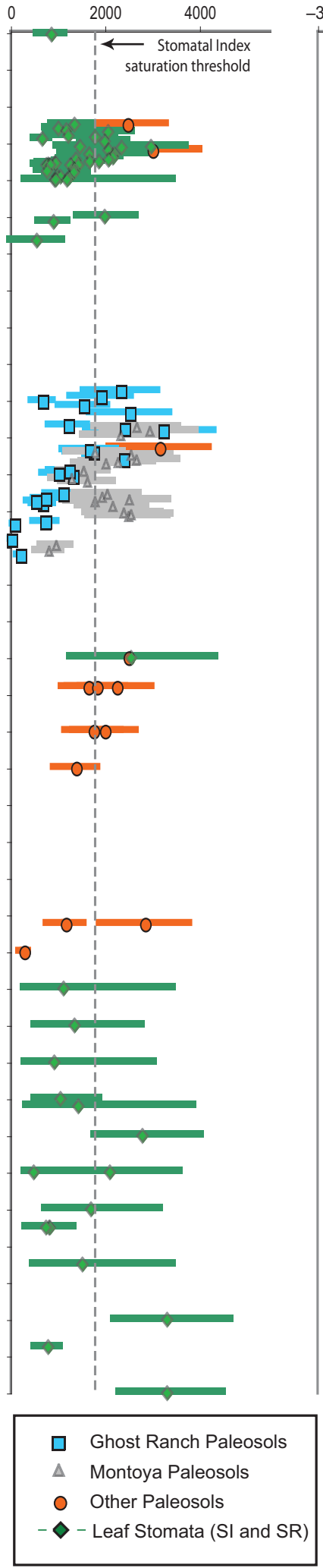

C

$\delta^{13} \mathrm{C}$

Marine Carbonates

(\%o)

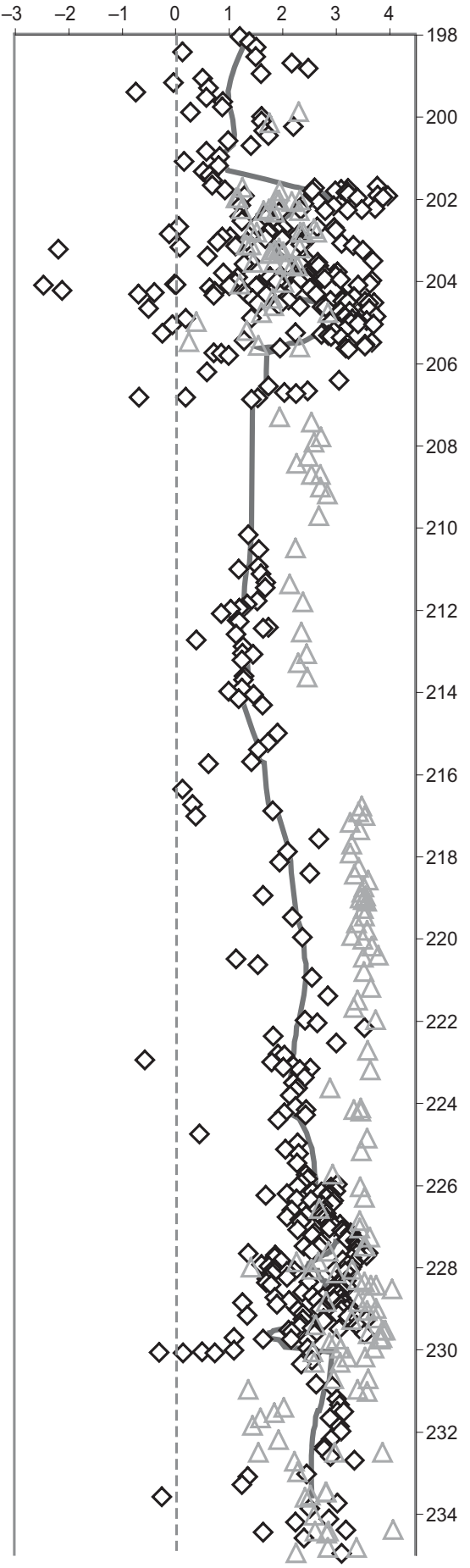

$\diamond$ Muttoni et al. (2014)

Muttoni et al. (2014)

$5 \%$ weighted mean

$\triangle$ Korte et al. (2005)

Figure 5. 
speculate on the detailed timing and size of the changes in continental weathering necessary to produce some of the finer-scale $p \mathrm{CO}_{2}$ changes we observe. However, the consistency of our results with a weathering-forced Triassic carbon cycle suggests that these details are clear targets for future GEOCLIM modeling efforts with more detailed paleogeography.

(3) These findings indicate that weathering may be an important driver of long-term changes in $p \mathrm{CO}_{2}$ during other time periods, simply by changes in the distribution and lithology of continental rocks (and especially subaerial basaltic provinces) with respect to the climate zones on Earth's surface where weathering is most effective (mainly the tropical humid belt).

\section{ACKNOWLEDGMENTS}

We are particularly grateful to Paul E. Olsen for his helpful discussion, Roy Schlische for reviewing an early draft of this manuscript, Elizabeth Miller for prepping organic samples, and Dan Breecker and an anonymous reviewer for comments that greatly improved this manuscript. This research was supported by National Science Foundation grant EAR-0958867. This is Lamont Doherty Earth Observatory Contribution 7840.

\section{REFERENCES CITED}

Arens, N.C., Jahren, A.H., and Amundson, R., 2000, Can C3 plants faithfully record the carbon isotopic composition of atmospheric carbon dioxide?: Paleobiology, v. 26, no. 1 , p. 137-164, doi:10.1666/0094-8373 (2000) $026<0137$ :CCPFRT>2.0.CO;2.

Bachan, A., van de Schootbrugge, B., Fiebig, J., McRoberts, C.A., Ciarapica, G., and Payne, J.L., 2012, Carbon cycle dynamics following the end-Triassic mass extinction: Constraints from paired $\delta^{13} \mathrm{Ccarb}$ and $\delta^{13} \mathrm{Corg}$ records: Geochemistry Geophysics Geosystems, v. 13, Q09008, doi:10.1029/2012GC004150.

Beerling, D.J., and Royer, D.L., 2002a, Fossil plants as indicators of the Phanerozoic global carbon cycle: Annual Review of Earth and Planetary Sciences, v. 30, p. 527556, doi:10.1146/annurev.earth.30.091201.141413.

Beerling, D.J., and Royer, D.L., 2002b, Reading a $\mathrm{CO}_{2}$ signal from fossil stomata: The New Phytologist, v. 153 , no. 3 , p. 387-397, doi:10.1046/j.0028-646X.2001.00335.x.

Bergman, N.M., Lenton, T.M., and Watson, A.J., 2004, COPSE: A new model of biogeochemical cycling over Phanerozoic time: American Journal of Science, v. 304, no. 5, p. 397-437, doi:10.2475/ajs.304.5.397.

Berner, R.A., 1990, Atmospheric carbon-dioxide levels over Phanerozoic time: Science, v. 249, no. 4975, p. 1382 1386, doi: $10.1126 /$ science. 249.4975 .1382 .

Berner, R.A., 1991, A model for atmospheric $\mathrm{CO}_{2}$ over Phanerozoic time: American Journal of Science, v. 291, no. 4, p. 339-376, doi:10.2475/ajs.291.4.339.

Berner, R.A., 2006, Inclusion of the weathering of volcanic rocks in the GEOCARBSULF model: American Journal of Science, v. 306, no. 5, p. 295-302, doi:10.2475 /05.2006.01

Berner, R.A., and Kothavala, Z., 2001, GEOCARB III: A revised model of atmospheric $\mathrm{CO}_{2}$ over Phanerozoic time: American Journal of Science, v. 301, no. 2, p. 182-204, doi:10.2475/ajs.301.2.182

Berner, R.A., Lasaga, A.C., and Garrels, R.M., 1983, The carbonate-silicate geochemical cycle and its effect on atmospheric carbon dioxide over the past 100 million years: American Journal of Science, v. 283, p. 641683, doi:10.2475/ajs.283.7.641.

Blackburn, T.J., Olsen, P.E., Bowring, S.A., McLean, N.M., Kent, D.V., Puffer, J., McHone, G., Rasbury, E.T., and Et-Touhami, M., 2013, Zircon U-Pb geochronology links the end-Triassic extinction with the Central At- lantic magmatic province: Science, v. 340, no. 6135, p. 941-945, doi:10.1126/science.1234204.

Breecker, D.O., 2013, Quantifying the uncertainty of atmospheric $\mathrm{CO}_{2}$ concentrations determined using paleosol carbonates: Geochemistry Geophysics Geosystems, v. 14, p. 3210-3220, doi:10.1002/ggge. 20189.

Breecker, D.O., Sharp, Z.D., and McFadden, L.D., 2009, Seasonal bias in the formation and stable isotopic composition of pedogenic carbonate in modern soils from central New Mexico, USA: Geological Society of America Bulletin, v. 121, no. 3-4, p. 630-640, doi: 10.1130/B26413.1.

Breecker, D.O., Sharp, Z.D., and McFadden, L.D., 2010, Atmospheric $\mathrm{CO}_{2}$ concentrations during ancient greenhouse climates were similar to those predicted for A.D. 2100: Proceedings of the National Academy of Sciences of the United States of America, v. 107, no. 2, p. 576-580, doi:10.1073/pnas.0902323106.

Cerling, T.E., 1999, Stable carbon isotopes in paleosol carbonates, in Thiry, M., and Simon-Coincon, R., eds. Palaeoweathering, Palaeosurfaces and Other Related Continental Deposits: International Association of Sedimentologists Special Publication 27, p. 43-60.

Cleveland, D.M., Nordt, L.C., Dworkin, S.I., and Atchley, S.C., 2008, Pedogenic carbonate isotopes as evidence for extreme climatic events preceding the TriassicJurassic boundary: Implications for the biotic crisis?: Geological Society of America Bulletin, v. 120, no. 11-12, p. 1408-1415, doi:10.1130/B26332.1.

Cotton, J.M., and Sheldon, N.D., 2012, New constraints on using paleosols to reconstruct atmospheric $p \mathrm{CO}_{2}$ : Geological Society of America Bulletin, v. 124, no. 9-10, p. 1411-1423.

DeConto, R.M., Pollard, D., Wilson, P.A., Palike, H., Lear, C.H., and Pagani, M., 2008, Thresholds for Cenozoic bipolar glaciation: Nature, v. 455 , no. 7213 , p. 652 656, doi:10.1038/nature07337.

Dessert, C., Dupre, B., Francois, L.M., Schott, J., Gaillardet, J., Chakrapani, G., and Bajpai, S., 2001, Erosion of Deccan Traps determined by river geochemistry: Impact on the global climate and the Sr-87/Sr-86 ratio of seawater: Earth and Planetary Science Letters, v. 188 , no. $3-4$, p. $459-474$, doi:10.1016/S0012-821X (01)00317-X.

Dessert, C., Dupre, B., Gaillardet, J., Francois, L.M., and Allegre, C.J., 2003, Basalt weathering laws and the impact of basalt weathering on the global carbon cycle: Chemical Geology, v. 202, no. 3-4, p. 257-273, doi:10 $.1016 /$ j.chemgeo.2002.10.001.

Donnadieu, Y., Goddéris, Y., Pierrehumbert, R., Dromart, G., Fluteau, F., and Jacob, R., 2006a, A GEOCLIM simulation of climatic and biogeochemical consequences of Pangea breakup: Geochemistry Geophysics Geosystems, v. 7, no. 11, Q11019, doi:10.1029 12006GC001278.

Donnadieu, Y., Pierrehumbert, R., Jacob, R., and Fluteau, F., 2006b, Modelling the primary control of paleogeography on Cretaceous climate: Earth and Planetary Science Letters, v. 248, no. 1-2, p. 426-437, doi:10.1016 /j.eps1.2006.06.007.

Driese, S.G., and Mora, C.I., 2002, Paleopedology and stable-isotope geochemistry of Late Triassic (CarnianNorian) paleosols, Durham Sub-Basin, North Carolina, USA: Implications for paleoclimate and paleoatmospheric $\mathrm{pCO}_{2}$, in Renaut, R.A., and Ashley, G.M., eds., Sedimentation in Continental Rifts: Society for Sedimentary Geology (SEPM) Special Publication 73, p. 207-218.

Ekart, D.D., Cerling, T.E., Montañez, I.P., and Tabor, N.J., 1999, A 400 million year carbon isotope record of pedogenic carbonate: Implications for paleoatmospheric carbon dioxide: American Journal of Science, v. 299, no. 10 , p. $805-827$, doi:10.2475/ajs.299.10.805.

Gaffin, S., 1987, Ridge volume dependence on seafloor generation rate and inversion using long term sea level change: American Journal of Science, v. 287, no. 6, p. 596-611, doi:10.2475/ajs.287.6.596.

Gaillardet, J., Dupre, B., Louvat, P., and Allegre, C.J., 1999, Global silicate weathering and $\mathrm{CO}_{2}$ consumption rates deduced from the chemistry of large rivers: Chemical Geology, v. 159, no. 1-4, p. 3-30, doi:10.1016/S0009 $-2541(99) 00031-5$.
Goddéris, Y., Donnadieu, Y., de Vargas, C., Pierrehumbert, R.T., Dromart, G., and van de Schootbrugge, B., 2008 , Causal or casual link between the rise of nannoplankton calcification and a tectonically-driven massive decrease in Late Triassic atmospheric $\mathrm{CO}_{2}$ ?: Earth and Planetary Science Letters, v. 267, no. 1-2, p. 247-255, doi:10.1016/j.eps1.2007.11.051.

Irmis, R.B., Mundil, R., Martz, J.W., and Parker, W.G., 2011, High-resolution U-Pb ages from the Upper Triassic Chinle Formation (New Mexico, USA) support a diachronous rise of dinosaurs: Earth and Planetary Science Letters, v. 309, no. 3-4, p. 258-267, doi:10.1016 /j.eps1.2011.07.015.

Katz, M.E., Wright, J.D., Miller, K.G., Cramer, B.S., Fennel, K., and Falkowski, P.G., 2005, Biological overprint of the geological carbon cycle: Marine Geology, v. 217 no. 3-4, p. 323-338.

Kent, D.V., and Muttoni, G., 2008, Equatorial convergence of India and early Cenozoic climate trends: Proceedings of the National Academy of Sciences of the United States of America, v. 105, no. 42, p. 16,065-16,070, doi:10.1073/pnas.0805382105

Kent, D.V., and Muttoni, G., 2013, Modulation of Late Cretaceous and Cenozoic climate by variable drawdown of atmospheric $p \mathrm{CO}_{2}$ from weathering of basaltic provinces on continents drifting through the equatorial humid belt: Climate of the Past, v. 9, p. 525-546, doi:10 $.5194 / \mathrm{cp}-9-525-2013$.

Kent, D.V., and Olsen, P.E., 1999, Astronomically tuned geomagnetic polarity timescale for the Late Triassic: Journal of Geophysical Research-Solid Earth, v. 104, no. B6, p. 12,831-12,841, doi:10.1029 /1999JB900076.

Kent, D.V., and Olsen, P.E., 2008, Early Jurassic magnetostratigraphy and paleolatitudes from the Hartford continental rift basin (eastern North America): Testing for polarity bias and abrupt polar wander in association with the Central Atlantic magmatic province: Journal of Geophysical Research-Solid Earth, v. 113, no. B6, B06105, doi:10.1029/2007JB005407.

Kent, D.V., and Tauxe, L., 2005, Corrected Late Triassic latitudes for continents adjacent to the North Atlantic: Science, v. 307 , no. 5707 , p. $240-244$, doi:10.1126 /science.1105826.

Kent, D.V., Olsen, P.E., and Witte, W.K., 1995, Late Triassic-earliest Jurassic geomagnetic polarity sequence and paleolatitudes from drill cores in the Newark rift basin, eastern North America: Journal of Geophysical Research, v. 100, p. 14,965-14,998, doi:10.1029 195JB01054.

Korte, C., Kozur, H.W., and Veizer, J., 2005, Delta C-13 and delta O-18 values of Triassic brachiopods and carbonate rocks as proxies for coeval seawater and palaeotemperature: Palaeogeography, Palaeoclimatology, Palaeoecology, v. 226 , no. 3-4, p. 287-306, doi:10 .1016/j.palaeo.2005.05.018.

Kump, L.R., Brantley, S.L., and Arthur, M.A., 2000, Chemical weathering, atmospheric $\mathrm{CO}_{2}$, and climate: Annual Review of Earth and Planetary Sciences, v. 28, no. 1, p. 611-667, doi:10.1146/annurev.earth.28.1.611.

Mack, G.H., James, W.C., and Monger, H.C., 1993, Classification of paleosols: Geological Society of America Bulletin, v. 105, no. 2, p. 129-136, doi:10.1130/0016 $-7606(1993) 105<0129:$ COP $>2.3$.CO;2.

Manabe, S., and Wetherald, R.T., 1980, On the distribution of climate change resulting from an increase in $\mathrm{CO}_{2}$ content of the atmosphere: Journal of the Atmospheric Sciences, v. 37, no. 1, p. 99-118, doi:10.1175/1520 -0469(1980)037<0099:OTDOCC>2.0.CO;2.

McElwain, J.C., Beerling, D.J., and Woodward, F.I., 1999 Fossil plants and global warming at the Triassic-Jurassic boundary: Science, v. 285, no. 5432, p. 1386-1390, doi:10.1126/science.285.5432.1386.

Montañez, I.P., 2013, Modern soil system constraints on reconstructing deep-time atmospheric $\mathrm{CO}_{2}$ : Geochimica et Cosmochimica Acta, v. 101, p. 57-75, doi:10.1016/j gca.2012.10.012

Muttoni, G., Mazza, M., Mosher, D., Katz, M.E., Kent, D.V., and Balini, M., 2014, A Middle-Late Triassic (Ladinian/Rhaetian) carbon and oxygen isotope record from the Tethyan Ocean: Palaeogeography, Palaeoclimatology, Palaeoecology, v. 399, p. 246-259. 
Nadelhoffer, K.F., and Fry, B., 1988, Controls on natura $\mathrm{N}-15$ and C-13 abundances in forest soil organicmatter: Soil Science Society of America Journal, v. 52, no. 6, p. 1633-1640, doi:10.2136/sssaj1988 $.03615995005200060024 x$.

Olsen, P.E., 1986, A 40-million year lake record of early Mesozoic orbital climatic forcing: Science, v. 234, p. 842-848, doi:10.1126/science.234.4778.842.

Olsen, P.E., 1997, Stratigraphic record of the early Mesozoic breakup of Pangea in the Laurasia-Gondwana rift system: Annual Review of Earth and Planetary Sciences, v. 25, p. 337-401, doi:10.1146/annurev.earth.25.1.337.

Olsen, P.E, and Kent, D.V., 1996, Milankovitch climate forcing in the tropics of Pangaea during the Late Triassic: Palaeogeography, Palaeoclimatology, Palaeoecology, v. 122 , no. 1-4, p. 1-26, doi:10.1016/0031-0182 (95)00171-9.

Olsen, P.E., and Kent, D.V., 1999, Long-period Milankovitch cycles from the Late Triassic and Early Jurassic of eastern North America and their implications for the calibration of the early Mesozoic time-scale and the long-term behaviour of the planets: Philosophical Transactions of the Royal Society of London, ser. A, Mathematical Physical and Engineering Sciences, v. 357 , no. 1757 , p. $1761-1786$.

Olsen, P.E., Kent, D.V., Cornet, B., Witte, W.K., and Schlische, R.W., 1996, High-resolution stratigraphy of the Newark rift basin (early Mesozoic, eastern North America): Geological Society of America Bulletin, v. 108 , no. 1 , p. 40-77, doi:10.1130/0016-7606 (1996) 108<0040:HRSOTN>2.3.CO;2.

Olsen, P.E., Kent, D.V., and Whiteside, J.H., 2011, Implications of the Newark Supergroup-based astrochronology and geomagnetic polarity time scale (Newark-APTS) for the tempo and mode of the early diversification of the Dinosauria: Earth and Environmental Science Transactions of the Royal Society of Edinburgh, v. 101, p. 1-33.

Quade, J., Cerling, T.E., and Bowman, J.R., 1989, Systematic variations in the carbon and oxygen isotopic composition of pedogenic carbonate along elevation transects in the southern Great Basin, United States: Geological Society of America Bulletin, v. 101, no. 4 p. 464-475, doi:10.1130/0016-7606(1989)101<0464 SVITCA $>2.3 . \mathrm{CO} ; 2$.
Rasbury, E.T., Gierlowski-Kordesch, E.H., Cole, J.M., Sookdeo, C., Spataro, G., and Nienstedt, J., 2006, Calcite cement stratigraphy of a nonpedogenic calcrete in the Triassic New Haven Arkose (Newark Supergroup), in Alonso-Zarza, A.M., and Tanner, L.H., eds., Paleoenvironmental Record and Applications of Calcretes and Palustrine Carbonates: Geological Society of America Special Paper 416, p. 203-221

Raymo, M.E., and Ruddiman, W.F., 1992, Tectonic forcing of late Cenozoic climate: Nature, v. 359, no. 6391 p. 117-122, doi:10.1038/359117a0.

Retallack, G.J., 2001, A 300-million-year record of atmospheric carbon dioxide from fossil plant cuticles: Nature, v. 411 , no. 6835 , p. 287-290, doi:10.1038/35077041.

Retallack, G.J., 2009a, Greenhouse crises of the past 300 million years: Geological Society of America Bulletin, v. 121, no. 9-10, p. 1441-1455, doi:10.1130/B26341.1.

Retallack, G.J., 2009b, Refining a pedogenic-carbonate $\mathrm{CO}_{2}$ paleobarometer to quantify a middle Miocene greenhouse spike: Palaeogeography, Palaeoclimatology, Palaeoecology, v. 281, no. 1-2, p. 57-65, doi:10.1016/j .palaeo.2009.07.011.

Romanek, C.S., Grossman, E.L., and Morse, J.W., 1992 Carbon isotopic fractionation in synthetic aragonite and calcite: Effects of temperature and precipitation rate: Geochimica et Cosmochimica Acta, v. 56, no. 1, p. 419-430, doi:10.1016/0016-7037(92)90142-6.

Schaller, M.F., Wright, J.D., and Kent, D.V., 2011, Atmospheric $p \mathrm{CO}_{2}$ perturbations associated with the Central Atlantic magmatic province: Science, v. 331, no. 6023, p. 1404-1409, doi:10.1126/science.1199011.

Schaller, M.F., Wright, J.D., Kent, D.V., and Olsen, P.E., 2012, Rapid emplacement of the Central Atlantic magmatic province as a net sink for $\mathrm{CO}_{2}$ : Earth and Planetary Science Letters, v. 323-324, p. 27-39, doi: 10.1016/j.epsl.2011.12.028.

Schidlowski, M., 2001, Carbon isotopes as biogeochemical recorders of life over $3.8 \mathrm{Ga}$ of Earth history: Evolution of a concept: Precambrian Research, v. 106, no. 1-2, p. 117-134, doi:10.1016/S0301-9268(00)00128-5.

Schubert, B.A., and Jahren, H.A., 2012, The effect of atmospheric $\mathrm{CO}_{2}$ concentration on carbon isotope fractionation in $\mathrm{C}_{3}$ land plants: Geochimica et Cosmochimica Acta, v. 96, p. 29-43.
Shirey, S.B., Cartigny, P., Frost, D.J., Keshav, S., Nestola, F., Nimis, P., Pearson, D.G., Sobolev, N.V., and Walter, M.J., 2013, Diamonds and the geology of mantle carbon: Reviews in Mineralogy and Geochemistry, v. 75 no. 1, p. 355-421, doi:10.2138/rmg.2013.75.12.

Smoot, J.P., 1991, Sedimentary facies and depositional en vironments of early Mesozoic Newark Supergroup basins, eastern North America: Palaeogeography, Palaeoclimatology, Palaeoecology, v. 84, p. 369-423.

Steinthorsdottir, M., Jeram, A.J., and McElwain, J.C., 2011 Extremely elevated $\mathrm{CO}_{2}$ concentrations at the Triassic/ Jurassic boundary: Palaeogeography, Palaeoclimatology, Palaeoecology, v. 308 , no. 3-4, p. 418-432, doi 10.1016/j.palaeo.2011.05.050.

Suchecki, R.K., Hubert, J.F., and Dewet, C.C.B., 1988, Isotopic imprint of climate and hydrogeochemistry on terrestrial strata of the Triassic-Jurassic Hartford and Fundy rift basins: Journal of Sedimentary Petrology, v. 58 , no. 5, p. 801-811.

Tanner, L.H., Hubert, J.F., Coffey, B.P., and McInerney, D.P., 2001, Stability of atmospheric $\mathrm{CO}_{2}$ levels across the Triassic/Jurassic boundary: Nature, v. 411 , no. 6838 , p. 675-677, doi:10.1038/35079548.

Van Houten, F.B., 1962, Cyclic sedimentation and the origin of analcime-rich Upper Triassic Lockatong Formation, west-central New Jersey and adjacent Pennsylvania: American Journal of Science, v. 260, p. 561-576, doi: 10.2475/ajs.260.8.561.

Walker, J.C.G., Hays, P.B., and Kasting, J.F., 1981, Negative feedback mechanism for the long-term stabilization of Earth's surface temperature: Journal Geophysical Research-Oceans, v. 86, p. 9776-9782.

Wang, Z.S., Rasbury, E.T., Hanson, G.N., and Meyers, W.J., 1998 , Using the U-Pb system of calcretes to date the time of sedimentation of clastic sedimentary rocks: Geochimica et Cosmochimica Acta, v. 62, no. 16, p. 2823-2835, doi:10.1016/S0016-7037(98)00201-4.

SCIENCE Editor: A. Hope JAHREN

Manuscript Received 5 April 2014

Revised Manuscript Received 23 September 2014

MANUSCRIPT ACCEPTED 20 OCTOBER 2014

Printed in the USA 